\title{
COLLECTIVE ACTION AND COLLECTIVE SCHEME IN THE MOBILIZATION OF LEARNING CHEMISTRY ACCORDING TO VERGNAUD'S THEORY OF CONCEPTUAL FIELDS
}

\author{
Lucia Machado de Andrade \\ Federal University of ABC, Brazil \\ E-mail: lucia.andrade@ufabc.edu.br \\ Káthia Maria Honório \\ University of São Paulo, Brazil \\ E-mail: kmhonorio@usp.br \\ Marco Antonio Bueno Filho \\ Federal University of ABC, Brazil \\ E-mail: marco.antonio@ufabc.edu.br
}

\begin{abstract}
This research's aim was to analyze the mobilization in learning chemistry promoted by the collective action of three entrant students in higher education courses, in a college located in Santo André. For such, cognitive indicators mobilized by them while living individual and group situations on water's boiling point, using Screencast video lessons as a motivational strategy, were analyzed. The fulfilment of these situations' corresponding tasks was filmed, and the recordings were transcribed and analyzed with the help from the Transana software. The indicators used for the Discursive Textual Analysis were created by associating Vicente Talanquer's Chemistry Knowledge Space to Gérard Vergnaud's Theory of Conceptual Fields. The results displayed higher quantity and better quality to the indicators in situations with collective character, to the detriment to the ones with individual character. Thus, one might conclude that, under this research's conditions, collective action, generated by a collective scheme, was capable of mobilizing the learning of chemistry.
\end{abstract}

Keywords: collective action, space of knowledge of chemistry, collective scheme, theory of conceptual fields.

\section{Introduction}

Learning chemistry is intimately related to the development of the capability to understand concepts (Treagust, Schmidt, \& Kaufmann, 2009) and establish relations between observable phenomena and the non-observable world of sub-atomic particles (Beltran, 1997), a process that has been widely reported, in literature, as problematic. The difficulty in learning chemistry has been attributed to the traditional methods of teaching this science (Armbrecht, Aragón-Muriel, \& Micolda, 2014; Suart, 2008). Chemical phenomena, for instance, are usually explained on a sub-microscopic level, leaving aside structural aspects (Johnstone, 1993). According to Rezende and Wartha (2011), the explanation to phenomena of molecular nature 
Lucia Machado de ANDRADE, Káthia Maria HONÓRIO, Marco Antonio BUENO FILHO. Collective action and collective scheme in the mobilization of learning chemistry according to Vergnaud's theory of conceptual fields

PROBLEMS

OF EDUCATION

IN THE $21^{\text {st }}$ CENTURY Vol. 75 , No. 5, 2017

420

originate from this teaching model (Armbrecht, Aragón-Muriel, \& Micolda, 2014), influencing the performance of students who entered university courses which had disciplines in the area of sciences. This teaching is faulty (Bagarukayo, Weide, Mbarika, \& Kim, 2012; Zoller, 1993, 2000, 2001), for it does not satisfy situations demanded by modern life, which means applying knowledge in real and daily situations.

The major goal in education in chemistry, according to Zoller (1993, 1999, 2000, 2001, 2004), is developing the ability to think critically, in a way that the student is capable of making decisions in order to solve problems. The author proposes the use of new teaching technologies, calling attention to the necessity breaking through the current paradigm, which aims at HOCS (higher-order cognitive skills) and proposes that, for such, it is necessary to promote revolutionary changes in education, especially in higher education.

Taqi and Al-Nouh (2014) put forth the educational proposal of works done in groups, which permit reaching HOCS, since students are impelled to discuss, argue, explain and negotiate meanings, besides defending that a rather evident effect of this methodology is the increase in motivation provided. Corroborating with this proposal, Kim and Tan (2013) warn that the ability to corroborate in order to carry out a group task does not come about by itself, but requires an explicit educational strategy, with well established guidelines, also proclaiming that such collaboration becomes more effective as the level of complexity of the task gets higher when it comes to decision processes in deciding on what to do in solving the problem.

In order to provide analysis on complex cognitive activities with a theoretical structure, Gérard Vergnaud elaborated in the 1990's the Theory of Conceptual Fields. It deals, fundamentally, with cognitive development (Vergnaud, 2009) and has been used as theoretical reference to this research. Vergnaud bears a fundamentally constructivist structure in his theory, proclaiming that knowledge is built through interactions between the learner and the situations they live and, thus, learning takes place as concepts become, over the course of many years, actual scientific concepts (Vergnaud, 2003). Piaget's main legacy for the Theory of Conceptual Fields was the concept of scheme (Vergnaud, 1991, 2009). According to him, the schemes are conceived as direct results from generalization of one's own actions, being of unperceivable nature (Palangana, 1998), but according to Vergnaud himself, his interpretation of the scheme is wider than Piaget's, defining it as a manner of conduct which, impregnated by this conceptual content (aspect not dealt with by Piaget), distinguishes the action by the subject before a class of situations, acting as the main architect of human thought (Vergnaud, 1991; 2009). In Vergnaud's view, the following constitute components of a scheme: (1) goals and anticipations, (2) action rules like "if-so-therefore", (3) operatory invariants and (4) probabilities of inference. Forming a concept, according to Vernaud, $(1991 ; 2009)$, is related to the triad S, I, R, in which S stands for situations, (which give the concepts meaning), I stands for operatory invariants (verbal and non-verbal, which give the concept its public characteristic) and $\mathrm{R}$ stands for the concept's symbolic representation, also in verbal and non-verbal fashions.

The core of Vergnaud's theory, however, is the concept of conceptual field. According to it, conceptual field is, at the same time, a set of situations and a set of concepts, all interrelated. The meaning of a concept cannot be analyzed through a single situation and, reciprocally, a situation cannot be analyzed through a single concept, but through many of them, creating systems.

Over the last ten years, works which use the Theory of Conceptual Fields as a reference have aimed mostly at education in mathematics, focusing mainly on subject matters such as scales and proportionality for assembling geometrical shapes (Dejarnette, Walczak, \& González, 2014), subtraction structures (Sánchez \& Fernández, 2009), additive structures (Magina, 2011) and multiplicative structures (Magina, Santos, \& Merlini, 2014). Some works aimed at physical education deal with the mechanism of wave propagation (Caballero, Pesa, \& Bravo, 2009), thermophysics (Carvalho Jr \& Aguiar Jr, 2008), gravitational interactions (Caballero, Moreira, $\&$ Stipcich, 2007), and others. In chemistry, there are not many works which use Vergnaud's 
theory as a reference. Among the most important, Bueno Filho's (2010), which proposed 16 multi-level tasks to students from the Chemistry Institute and the Faculty of Pharmaceutical Science of University of Sao Paulo, Brazil, in a way that they could actively and reflexively participate in the situations proposed can be quoted. The activities were related to getting to know their own conceptions, applying knowledge directly, confronting and relating their ideas to other participating peers' ideas and reworking conceptions, all related to the subject matter stereochemistry. The results led to a proposition which diverged from those presented by Vergnaud, stating that in a single class of situations, there was no regularity in the mobility of the same operatory invariants. Another important work which used the Theory of Conceptual Fields in chemistry was Caballero's, Grings' and Moreira's (2006), which analyzed difficulties in learning concepts related to thermodynamics (heat, temperature, work, entropy and energy) presented by 90 students from a technical school in Rio Grande do Sul, Brazil, seeking possible operatory invariants presented by them. Researchers suggest that these likely operatory invariants might represent obstacles to conceptualization, pointing at the occurrence of many that move away from scientific knowledge, potentially building obstacles to learning concepts.

\section{Collective Action and Collective Scheme}

In the field of education, there is no consensual definition to the term 'collective action', nor there are on the existence of something like 'theory of collective action'. When it is occasionally mentioned in the field of education, it is mostly related to the formation of groups of teachers who intend to modify school syllabuses or create new teaching methodologies. Thus, in this research, the term 'collective action' was appropriated, meaning students making decisions in groups, referring to the concepts that surround the topic 'water boiling point'. It is also inferred that this collective action is a reflex of the group's way of thinking, their collective scheme. It seems acceptable that individuals who live a certain situation in a group act accordingly to their individual conscience, or individual schemes, where a 'collective consciousness' or collective scheme, motor of the action, comes up, as Marcel (2007) defends: "collective scheme would be a structure which generates collective action in a given situation. The difference [between individual scheme and collective scheme], however, lies in the fact that this collective pattern is 'carried out' by a group of acting individuals, not by a single individual. The collective scheme is built and mobilized by the team, as a social and cognitive entity" (Marcel, 2007, p. 651). Besides, Marcel (2007) defends that the organization of patterns in individual schemes constitutes the specificity of the collective scheme, which has a cognitive surplus that would, in return, also influence individual schemes. That is, there would be some influence (not simply a joint) from individual schemes on the constitution of collective scheme and, in return, the new individual schemes would have been influenced and modified by this collective scheme. What is proclaimed in this research is precisely the account seen here: it is supposed that the students participating carrying out the tasks proposed have built, through their individual schemes, a collective scheme that, in turn, modified the individual schemes, entailing movement in their learning. Verdier (2007) studied the cognitive aspects in learning children, in the formation of initial concepts, through analyzing collective schemes produced by their collective actions, and concluding through the results obtained that learning through collective action can enrich students' individual patterns.

In Brazil, Bueno Filho, Nascimento and Alves (2015) paved the way to research related to collective actions and schemes, presenting their work in the field of intermolecular interactions, in which they also defend that the discourse of each individual participating in a situation lived collectively creates a collective unconscious characterized by contributions from individual schemes. That collective unconscious would be the collective scheme. 
Lucia Machado de ANDRADE, Káthia Maria HONÓRIO, Marco Antonio BUENO FILHO. Collective action and collective scheme in the mobilization of learning chemistry according to Vergnaud's theory of conceptual fields

PROBLEMS

OF EDUCATION

IN THE $21^{\text {st }}$ CENTURY Vol. 75, No. 5,2017

422

\section{Problem of Research}

The research objects are students in individual and collective learning actions, motivated by using screencast video lessons, with the purpose of presenting a methodological proposal which helps develop the HOCS, which, as Zoller (1993) suggests, would be the highest purpose of education in chemistry. For such, it is necessary that new teaching technologies be used, in order to develop rational evaluative thought.

The choice made here was to work with video lessons, which fit into the context of the new teaching strategies needed for developing HOCS (Blonder, Jonatan, Bar-Dov, Benny, Rap, \& Sakhnini, 2013; Chiu \& Wa, 2009; Sadik, 2015; Turkoguz, 2012; Zoller, 2001, 2000, 1999, 1993), since they are not used merely as expositional lessons which, in spite of being mediated, might not be as traditional as if they were taught with chalk and blackboard by a teacher in the center of the educative process. What justifies the use of this resource the way it has been presented in this research is that producing a video class stimulates and motivates the student to get more involved in the process of acquiring scientific concepts (Bailey, Hendricks \& Applewhite, 2015; Blonder, Jonatan, Bar-Dov, Benny, Rap, \& Sakhnini, 2013; Chiu \& Wa, 2009; Sadik, 2015; Sherer \& Shea, 2011; Smith, 2014; Turkoguz, 2012) so that they will have resources to present them in a suitable way, in both individual and collective aspects, constituting, besides that, a challenging and mobilizing teaching strategy of the HOCS (Suart, 2008). The screencast modality for the video class was chosen bearing in mind preserving the images of the students who produced them, enabling them to feel more at ease, thus motivating them to more intensely engage in the tasks proposed (Dunn, McDonald, \& Loch, 2015; Sherer \& Shea, 2011).

The choice of promoting a job done in group was made in function of the purpose to integralize the socialization of the forms of thought among the members, in a way that they would develop not only an environment which is collaborative on the superposition of ideas, but also participative in the conception of a collective scheme, which triggers collective action (Bronckart, 2007; Kim \& Tan, 2013; Marcel, 2005, 2007; Taqi \& Al-Nouh, 2014; Verdier, 2007). Thus, they debate, ponder, evaluate, construct and deconstruct their concepts taking as basis collective rationalization of what seems to be scientifically more plausible to them. To this gain in knowledge, an important teaching guide is added: once the hindering obstacles which are hindering or even preventing the learner's intellectual progress are known, the teacher has resources to offer more suitable ways to achieving their goals.

The chemistry topic chosen was the boiling point of water, because it is rich when it comes to the possibility of mobilizing ideas related to the structural (chemical bonds, electronegativity, polarity, among others) and thermodynamic (heat, enthalpy, entropy, among others) conceptual fields, and can be described on different levels of education, since the topic 'boiling point' is approached on the early stages of elementary school and moves on, being approached in slightly greater depth in high school.

What justifies the execution of this research, socially and culturally, is the idea of being able to contribute with advances in the area of education (which would influence a society's culture), both in learning, presenting a new proposal for students' motivation, encouragement and engagement in a group, through the specific proposal of a screencast production, and in teaching, as an aiding instrument to the investigation of students' forms of thought, which would collaborate with teachers' work in helping increase conceptual relations their students build, in qualitative and quantitative terms, thus helping them develop HOCS.

The main focus of this research was to obtain answers to the following basic questions:

1) Can collective action in producing a screencast video lesson contribute to building a collective scheme? What would this collective scheme be like in relation to individual schemes, if they were mobilized in different situations?

2) Can collective action, once it is generated by collective scheme, mobilize learning related to a specific topic in chemistry? What would the conceptual fields mobilized for this topic be? 
To obtain answers to the questions presented, the research aimed specifically at:

1) Analyzing cognitive indicators mobilized by the students involved in this research during the execution of situations of individual character;

2) Characterizing individual schemes of participating students, starting from the indicators analyzed;

3) Analyzing cognitive indicators mobilized by the same students involved before, this time during execution of situations of collective character;

4) Identifying characteristics of the scheme presented by the group, starting from these indicators analyzed.

Although the theory presented by Vergnaud deals specifically with individual schemes, it does not refute the existence of a collective scheme. Through this research, the intend is to aggregate the ideas defended by Bueno Filho, Nascimento and Alves (2015), Bronkcart (2007), Verdier (2007) and Marcel $(2005,2007)$, on the existence of collective schemes, to the Theory of Conceptual Fields. Also, it was through the comparison between the individual and collective schemes which the students presented that it was possible to verify and infer on the learning movement by the participating students. The existence of the collective scheme, collective action having been a reflex of this scheme and learning having been mobilized by this action, are inferences which could be made with basis on comparisons between the characteristics of individual schemes and the group scheme, as is accounted above, and as is intended to demonstrate throughout this text.

\section{Methodology of Research}

\section{General Background of Research}

In order to answer the basic questions presented, the cognitive indicators mobilized by the students while solving different types of actions (individual and collective) were analyzed during the months of August 2015 to March 2016, and, through them, have a panorama on the respective schemes.

The situations proposed which permitted such investigations were divided into two groups. Group 1 consisted of two situations lived by the students individually, while the second consisted of two situations lived in a group, which demanded greater involvement in viewpoint defense, development of critical sense and decision making in order to accomplish the tasks proposed, with both groups using video lessons in different contexts (in group 1, watching only, and in group 2, elaborating and creating), but belonging to the same topic, the boiling point of water.

The existence of collective scheme and the fact that the collective action originated from it, are hypotheses which can be inferred through the difference between individual and group schemes.

If the group's scheme displays conceptual correlations between the cognitive indicators analyzed, different from those which were presented in the individual schemes, the scheme related to the group's actions is not just a superposition or addition of individual schemes. In other words, new conceptual correlations came about from the group's weightings and reflections, allowing us to infer that the scheme is actually collective, and therefore the collective actions were produced by a collective scheme.

The hypothesis that collective action, once commanded by a collective scheme, mobilized the learning of chemistry related to a particular topic (in this case, the boiling point of water), can also be attributed to the difference between individual and group schemes. If the collective scheme presents greater richness and diversity (in quantity and quality) in the conceptual correlations between the cognitive indicators analyzed, it is to the group that this favorable difference in the conceptual correlations (relations between concepts and operatory invariants) that came about can be attributed, that is, weightings, reflections, insertions, questioning and 
Lucia Machado de ANDRADE, Káthia Maria HONÓRIO, Marco Antonio BUENO FILHO. Collective action and collective scheme in the mobilization of learning chemistry according to Vergnaud's theory of conceptual fields

OF EDUCATION

IN THE $21^{\text {st }}$ CENTURY Vol. 75 , No. 5, 2017

424

reconsiderations which led to a final conceptualization which was richer than the one presented individually. Therefore, collective action culminated in learning chemistry relating to the boiling point of water.

\section{Participants and Setting}

From March to May 2015, a pilot project was carried out with two students of the first year of the Pharmacy Course at Faculty of Medicine of ABC, a Higher Education Institution from the private network in Santo André, Brazil. On the occasion, the data collected had its results analyzed and validated by a team of specialists from the Federal University of ABC.

After completion of the pilot project and validation of procedures and data analysis instruments, three students, under the same conditions as the two first were, were chosen at random and by lot, that is, students from the same Education Institution, from the first year of the Pharmacy Course, ranging from 18 to 35 years of age, without a scholarship or prior professional qualification, one male and two females. Two of these students carried out their high school studies at schools from the public network, whereas one did it at a school from the private network.

\section{Instrument and Procedures}

The participant students experienced four situations, denominated S1, S2, S3 and S4, and went through 2 interviews, denominated E1 and E2. Table 1 shows the main characteristics of the situations and interviews carried out.

Table 1. Characteristics of situations and interviews experienced.

\begin{tabular}{|c|c|c|c|c|c|}
\hline $\begin{array}{l}\text { Situa- } \\
\text { tion }\end{array}$ & Description & $\begin{array}{l}\text { Action } \\
\text { scheme }\end{array}$ & Complexity level & Goal & Purpose \\
\hline S1 & $\begin{array}{l}\text { Student explains } \\
\text { and represents, on } \\
\text { blackboard, the boiling } \\
\text { point of water }\end{array}$ & Individual & More simple & $\begin{array}{l}\text { Analyze cogni- } \\
\text { tive indicators } \\
\text { presented by } \\
\text { student and } \\
\text { relates them to } \\
\text { the phenomenon } \\
\text { 'boiling' }\end{array}$ & $\begin{array}{l}\text { Infer on the level of } \\
\text { knowledge on 'boiling' } \\
\text { displayed by student, } \\
\text { in order to have com- } \\
\text { parison parameters } \\
\text { when analyzing data } \\
\text { from S3 (compare in- } \\
\text { dividual and collective } \\
\text { schemes) }\end{array}$ \\
\hline $\begin{array}{l}\text { Show } \\
\text { of } V_{\text {of }}\end{array}$ & $\begin{array}{l}\text { Student watches a } \\
\text { video lesson with } \\
\text { concepts related to the } \\
\text { topic 'boiling' }\end{array}$ & Individual & $\begin{array}{l}\text { Only information } \\
\text { input }\end{array}$ & $\begin{array}{l}\text { Present a learn- } \\
\text { ing object related } \\
\text { to the topic 'boil- } \\
\text { ing' }\end{array}$ & $\begin{array}{l}\text { Infer on student's } \\
\text { perception of concepts } \\
\text { which are pertaining } \\
\text { and non-pertaining to } \\
\text { the topic 'boiling' }\end{array}$ \\
\hline S2 & $\begin{array}{l}\text { Student explains } \\
\text { and represents, on } \\
\text { blackboard, what they } \\
\text { would change (if they } \\
\text { would) in their model } \\
\text { or video lesson }\end{array}$ & Individual & More simple & $\begin{array}{l}\text { Analyze cognitive } \\
\text { indicators }\end{array}$ & $\begin{array}{l}\text { Infer on the influence } \\
\text { of watching a video } \\
\text { lesson on the cognitive } \\
\text { level }\end{array}$ \\
\hline S3 & $\begin{array}{l}\text { Group discusses the } \\
\text { boiling point of water } \\
\text { with sodium chloride } \\
\text { and creates lesson to } \\
\text { explain the phenom- } \\
\text { enon }\end{array}$ & Collective & $\begin{array}{l}\text { More complex, } \\
\text { with greater } \\
\text { evidence of criti- } \\
\text { cal thinking and } \\
\text { questionings }\end{array}$ & $\begin{array}{l}\text { Analyze cognitive } \\
\text { indicators pre- } \\
\text { sented by group }\end{array}$ & $\begin{array}{l}\text { Infer on a possible } \\
\text { movement on group's } \\
\text { and each individual's } \\
\text { cognitive level by } \\
\text { comparing quality and } \\
\text { quantity of indicators } \\
\text { (comparing collective } \\
\text { to individual schemes) }\end{array}$ \\
\hline
\end{tabular}




\begin{tabular}{|c|c|c|c|c|c|}
\hline S4 & $\begin{array}{l}\text { Group creates lesson } \\
\text { and designs a video } \\
\text { lesson based on it }\end{array}$ & Collective & $\begin{array}{l}\text { More complex, } \\
\text { with greater } \\
\text { evidence of criti- } \\
\text { cal thought and } \\
\text { decision making }\end{array}$ & $\begin{array}{l}\text { Observe group's } \\
\text { decision making } \\
\text { and verify the } \\
\text { likely emergence } \\
\text { of concept not } \\
\text { presented in } \\
\text { previous tasks }\end{array}$ & $\begin{array}{l}\text { Permit finalization of } \\
\text { works through the ex- } \\
\text { ecution of their efforts' } \\
\text { final product }\end{array}$ \\
\hline E1 & $\begin{array}{l}\text { Student goes through } \\
\text { semi-structured inter- } \\
\text { view upon finalization } \\
\text { of S4 }\end{array}$ & Individual & $\begin{array}{l}\text { Simple enough } \\
\text { to express their } \\
\text { ideas, thoughts } \\
\text { and feelings }\end{array}$ & $\begin{array}{l}\text { Get to know } \\
\text { student's percep- } \\
\text { tion as to fulfilling } \\
\text { group work }\end{array}$ & $\begin{array}{l}\text { Confirm hypothesis of } \\
\text { existence of collec- } \\
\text { tive scheme under } \\
\text { the viewpoint from } \\
\text { other participants in the } \\
\text { research, besides the } \\
\text { researcher (students) }\end{array}$ \\
\hline E2 & $\begin{array}{l}\text { Student goes through } \\
\text { semi-structured } \\
\text { interview sometime } \\
\text { after living situations } \\
\text { aforementioned }\end{array}$ & Individual & $\begin{array}{l}\text { Simple enough to } \\
\text { clarify their way of } \\
\text { thinking }\end{array}$ & $\begin{array}{l}\text { Understand the } \\
\text { student's way of } \\
\text { thinking which } \\
\text { was not made } \\
\text { clear though } \\
\text { executing the } \\
\text { situations afore- } \\
\text { mentioned }\end{array}$ & $\begin{array}{l}\text { Confirm or refute the } \\
\text { interpretation of some } \\
\text { data through direct } \\
\text { explanation to student }\end{array}$ \\
\hline
\end{tabular}

\section{Data Analysis}

The analysis of the data was done through an essentially qualitative bias and, as a helping tool for the analysis of situations S1 to S4, the software Transana (WCER, 2011) was chosen. Through Transana, it is possible to show the temporal superposition of action scheme contents during the resolution of the situations proposed, which is basis for the Discursive Textual Analysis (DTA) carried out. For interviews E1 and E2, the analysis did not follow the same course as in situations S1 to S4, since they bring only students' opinions and contemplative clarifications.

The cognitive indicators utilized on this research's data treatment correspond to subgroups of meaning and represent a mesh of Vicente Talanquer's Chemical Knowledge Space (Talanquer, 2011), the approaches, dimensions, levels or scales and types, relating more to the structure of the narrative, or discourse analysis, as is proposed by Moraes and Galiazi (2006), and elements relating more to their contents and their articulations with thought operations, according to Vergnaud $(1991,2003,2009,2012)$, the concepts, explanations, gestures and operatory invariants. These cognitive indicators are listed on Table 2. 
Lucia Machado de ANDRADE, Káthia Maria HONÓRIO, Marco Antonio BUENO FILHO. Collective action and collective scheme in the mobilization of learning chemistry according to Vergnaud's theory of conceptual fields

PROBLEMS

OF EDUCATION

IN THE $21^{\text {st }}$ CENTURY Vol. 75 , No. 5, 2017

Table 2. Cognitive indicators utilized for DTA.

\begin{tabular}{|c|c|c|c|}
\hline Axis & Indicator & Axis & Indicator \\
\hline Gestures & $\begin{array}{l}\text { Baton } \\
\text { Cohesive } \\
\text { Demonstrative } \\
\text { Iconic } \\
\text { Metaphoric }\end{array}$ & Approaches & $\begin{array}{l}\text { Conceptual } \\
\text { Contextual } \\
\text { Historic } \\
\text { Mathematical }\end{array}$ \\
\hline Concepts & $\begin{array}{l}\text { Heat } \\
\text { Electronegativity and polarity } \\
\text { Kinetic energy } \\
\text { Entropy } \\
\text { Intermolecular bonds } \\
\text { Matter } \\
\text { Change of physical state } \\
\text { Atmospheric pressure } \\
\text { Steam pressure } \\
\text { Temperature }\end{array}$ & Levels or Scales & $\begin{array}{l}\text { Macroscopic } \\
\text { Mesoscopic } \\
\text { Molecular } \\
\text { Multiparticles } \\
\text { Subatomic } \\
\text { Supramolecular }\end{array}$ \\
\hline Explanations & $\begin{array}{l}\text { Conclusion } \\
\text { Justification }\end{array}$ & Types & $\begin{array}{l}\text { Experiences } \\
\text { Models } \\
\text { Visualizations }\end{array}$ \\
\hline Operatory invariants & $\begin{array}{l}\text { Conceive hypotheses } \\
\text { Consider possibilities } \\
\text { Carry out comparisons }\end{array}$ & Dimensions & $\begin{array}{l}\text { Composition and structure } \\
\text { Energy } \\
\text { Time }\end{array}$ \\
\hline
\end{tabular}

\section{Results of Research}

Figures 1 and 2 show the diagram obtained by the Transana software through DTA of the transcription from S1 and S2 to A1. The same can be seen for A2 in figures 3 and 4, and for A3 in figures 5 and 6. Figure 7 shows S3's diagram. The horizontal line above the colored bars indicates the time, in minutes and seconds (00:00), used by the group of students living S3. The length of the colored bars corresponds to the time in which the student manifested the cognitive indicator related on the left column. The bars represent different meaning units selected according to the main topic approached by the students in their explanations at that time.

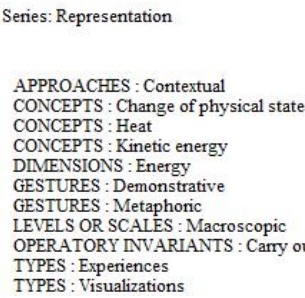

Figure 1. DTA Diagram of A1 in S1, obtained by Transana. 
Lucia Machado de ANDRADE, Káthia Maria HONÓRIO, Marco Antonio BUENO FILHO. Collective action and collective scheme in the mobilization of learning chemistry according to Vergnaud's theory of conceptual fields

Series: Reflection

APPROACHES : Conceptual

CONCEPTS : Change of physical state

CONCEPTS : Heat

DTENSIONS Composition and structure

DIMENSIONS : Energy

DIMENSIONS : Time

LEVELS OR SCALES : Molecula

OPERATORY INVARIANTS : Carry out comparison

Figure 2. DTA Diagram of A1 in S2, obtained by Transana.

LEVELS OR SCALES : Macroscopic
Series: Representation

APPROACHES : Conceptual

CONCEPTS : Atmospheric pressure.

CONCEPTS : Change of physical stat

CONCEPTS : Heat

CONCEPTS : Kinetic

CONCEPTS : Temperature

DIMENSIONS : Composition and structure

DIMENSIONS : Energ

EXPLANATTONS : Conclusion

GESTURES : Demonstrative

GESTURES : Metaphon

LEVELS OR SCALES : Molecular

OPERATORY INVARIANTS : Carry out comparisons

OPERATORY INVARIANTS : Conceive hypotheses

OPERATORY INVARIANTS : Consider possibilities

TYPES : Experience

TYPES : Visualizations

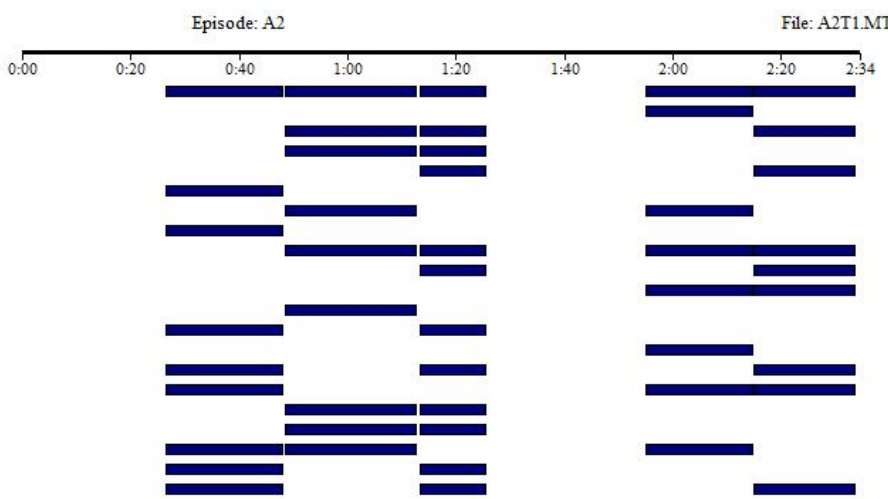

Figure 3. DTA Diagram of A2 in S1, obtained by Transana.

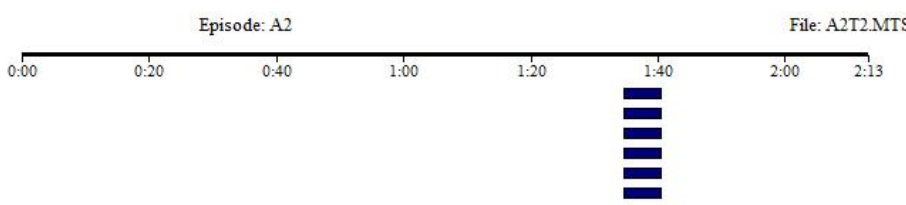

Figure 4. DTA Diagram of A2 in S2, obtained by Transana.

Series: Representation

APPROACHES : Conceptual

CONCEPTS : Intermolecular bonds

CONCEPTS : Kinetic energy

CONCEPTS : Matter

DIMENSIONS : Composition and structure

DMENSIONS : Energy

Dustification

LEVELS OR SCALES : Macroscopic

LEVELS OR SCALES : Molecular

LEVELS OR SCALES : Supramolecular

OPERATORY INVARIANTS : Carry out comparison

D

TYPES : Models

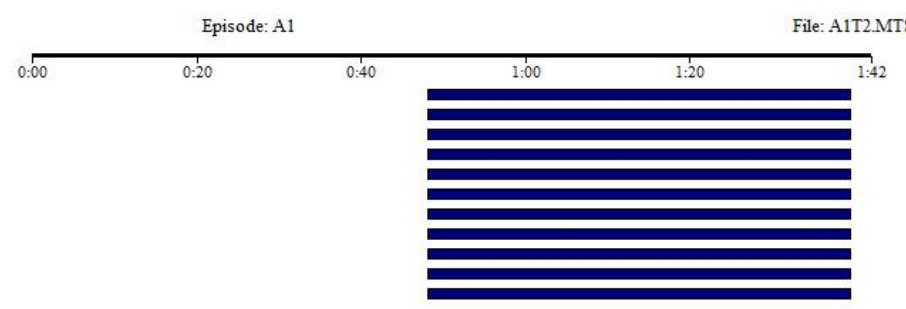

PROBLEMS

OF EDUCATION

IN THE $21^{\text {st }}$ CENTURY

Vol. 75, No. 5, 2017 
Lucia Machado de ANDRADE, Káthia Maria HONÓRIO, Marco Antonio BUENO FILHO. Collective action and collective scheme in the mobilization of learning chemistry according to Vergnaud's theory of conceptual fields

PROBLEMS

OF EDUCATION

IN THE $21^{\text {st }}$ CENTURY Vol. 75 , No. 5, 2017

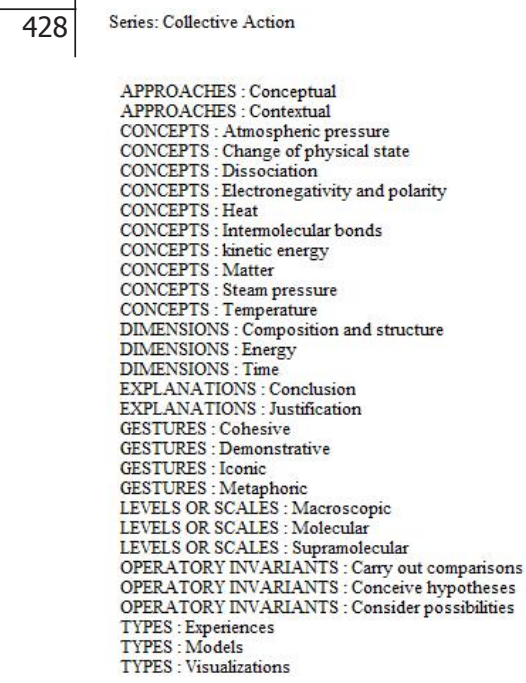

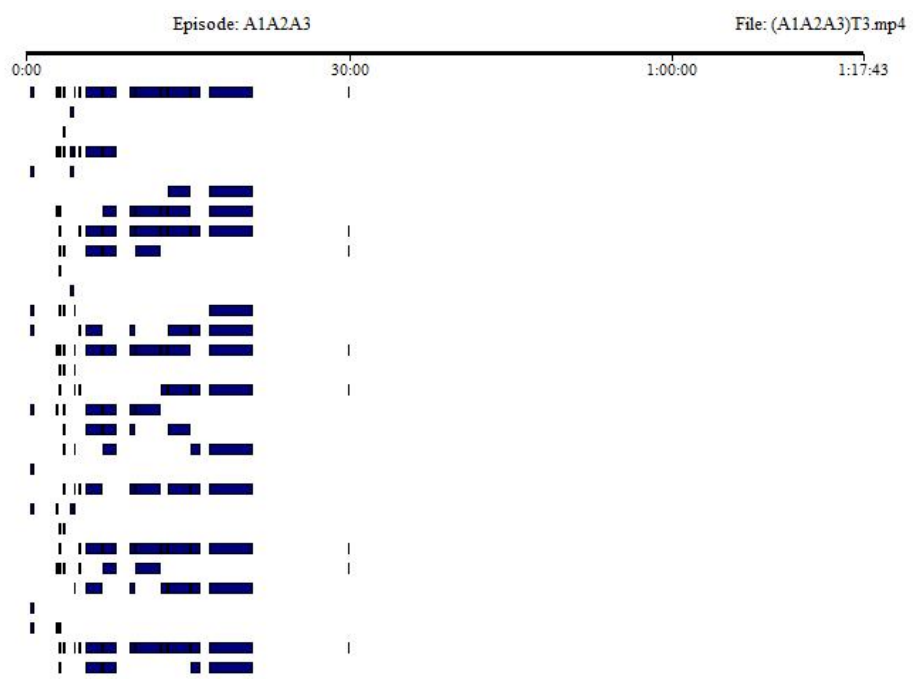

Figure 7. DTA Diagram of S3, obtained by Transana.

Table 3 shows the main results obtained when we compare each student's performance experiencing individual situations (S1 and S2) to the group's performance, experiencing a collective situation (S3).

Table 3. Comparative results between individual and group situations.

\begin{tabular}{llll}
\hline Result & $\begin{array}{l}\text { S1 and } \\
\text { S2 }\end{array}$ & S3 & Difference \\
\hline $\begin{array}{l}\text { Quantity of cognitive indicators } \\
\text { considered for analysis }\end{array}$ & 36 & 37 & Dissociation entered S3 \\
\hline
\end{tabular}

\begin{tabular}{|c|c|c|c|}
\hline \multirow{3}{*}{$\begin{array}{l}\text { Total quantity of cognitive indica- } \\
\text { tors mobilized }\end{array}$} & A1: 16 & \multirow{3}{*}{30} & \multirow{3}{*}{$\begin{array}{l}\text { Subatomic scale appeared in S1 } \\
\text { Concepts of electronegativity and polarity and steam pres- } \\
\text { sure appeared in S3 } \\
\text { Cohesive gesture appeared in S3 }\end{array}$} \\
\hline & A2: 21 & & \\
\hline & A3: 18 & & \\
\hline $\begin{array}{l}\text { Total quantity of concepts consid- } \\
\text { ered for analysis }\end{array}$ & 10 & 11 & Dissociation entered S3 \\
\hline Association between concepts & 8 & 18 & \\
\hline \multirow{3}{*}{$\begin{array}{l}\text { Total quantity of mobilized con- } \\
\text { cepts }\end{array}$} & $\mathrm{A} 1: 4$ & \multirow{3}{*}{10} & \multirow{3}{*}{$\begin{array}{l}\text { Besides dissociation, the concepts of electronegativity and } \\
\text { polarity, pressure and steam were mobilized in S3 }\end{array}$} \\
\hline & A2: 6 & & \\
\hline & A3: 3 & & \\
\hline \multirow{3}{*}{$\begin{array}{l}\text { Total quantity of operatory invari- } \\
\text { ants }\end{array}$} & $\mathrm{A} 1: 2$ & \multirow{3}{*}{20} & \multirow{3}{*}{$\begin{array}{l}\text { Operatory invariants with a higher number of conceptual } \\
\text { associations were detected in S3 }\end{array}$} \\
\hline & A2: 9 & & \\
\hline & A3: 4 & & \\
\hline
\end{tabular}


The S4 situation did not show cognitive indicators or relations between them which differed from what occurred in S3, since it represented just an operational stage of the video lesson's production, in which the group reproduced, via recording, what they had already discussed in S3.

Student A1 associated concepts in the fulfilment of group 1 situations, A2 worked out 6 associations and student A3 worked out 1 as well. The group, through the fulfillment of situation S3, worked out 18 associations between concepts. Thus, the gains are taken into account, considering that the group's range should be attributed to each student, as the elaboration of a collective scheme is being considered (and, therefore, that which belongs to everybody belongs to each one): 17 for $\mathrm{A} 1,12$ for $\mathrm{A} 2$ and 17 for $\mathrm{A} 3$.

\section{Discussion}

The results of this research show a positive impact on students' learning and, as Blonder, Jonatan, Bar-Dov, Benny, Rap and Sakhnini (2013); Demissie, Ochonogor and Engida (2011); Sherer and Shea (2011); and Talanquer (2014) report, the choice of didactic material (the screencast video lesson) may have contributed to motivating them towards engaging on the knowledge construction process.

Taking into account each student's individual performance, it is possible to consider an increase of 6 concepts for A1, 4 for A2 and 7 for A3, that is, taking into consideration the existence of collective scheme, it is estimated that each one has mobilized the 10 concepts in S3. The conceptual gain of each student throughout the situations lived, from group 1's tasks to group 2's, was not merely in absolute quantities, but also in quality, for the use of the concepts, in S3, occurred in a fashion much more associated with other concepts than in S1 and S2.

The concepts mobilized refer to the structural (electronegativity and polarity, intermolecular bonds, matter, change of physical state) and thermodynamics' (heat, kinetic energy, entropy, atmospheric pressure, steam pressure and temperature) concepts, with the structural ones having been more widely accessed. The explicitation of operatory invariants was an important evidence for the recognition of mobilization in learning, as Caballero, Grings and Moreira (2006) concluded, in their work, on the conceptual field of thermodynamics.

The larger quantity of conceptual correlations worked out by the group in S3 was noteworthy, as did Marcel (2009) in his study, yielding the inference that the collective scheme was richer than any of the individual schemes and, although many operatory invariants which disagree with the currently accepted scientific model have sprung up, it is important that two aspects be taken into account. The first one is that a greater number of incorrect operatory invariants does not necessarily mean that the student is making more mistakes, but they are exposing their thoughts more. Second, this larger number may indicate that the student is establishing more conceptual connections, that is, they are accomplishing learning, according to Vergnaud's concept. Thus, it is believed that the ascending movement in learning can be associated to the absolute number of operatory invariants detected, and not to the number of them which is in agreement or disagreement with the current scientific model. Those who expose what they think are moving towards learning and, therefore, are building knowledge.

If each student's way of thinking, in their individual actions, is compared to the way of thinking related to the group, in a collective action, influences from each individual in the group are noticed, with indicators collectively mobilized which have been frequent for one or two participants, as well as influences from the group on each individual, through the appearance of indicators not frequently mobilized in individual actions. Thus, the differences observed bestow a certain comfort in proposing, once again, the existence of a collective scheme, as Bronckart (2007), Bueno Filho (2010), Marcel (2009), and Verdier (2007), in their works, also proposed the existence of such schemes. 
Lucia Machado de ANDRADE, Káthia Maria HONÓRIO, Marco Antonio BUENO FILHO. Collective action and collective scheme in the mobilization of learning chemistry according to Vergnaud's theory of conceptual fields

PROBLEMS

OF EDUCATION

IN THE $21^{\text {st }}$ CENTURY Vol. 75 , No. 5, 2017

430

\section{Conclusions}

The results displayed on this research show that, in individual actions, the students evidenced schemes with superficial explanations, restricted to supplying information or descriptions which were essentially macroscopic, with few cognitive indicators and few mobilized concepts which, when utilized, demonstrated to have few co-relational articulations established. On the other hand, in collective action, the students built a scheme that, differently from a simple sum of individual standpoints, was characterized by the group's re-elaboration of concepts, re-articulation of ideas and reconsideration of each individual's initial thoughts. Collective action, resulting from this scheme, evidenced the mobilization of new concepts and new relations between cognitive indicators, not seen in individual schemes.

The cognitive gains, associated to the situations lived collectively, represent a group structuring of thought, that is, reflect the collective scheme that formed from a group's cohesion, and not from overlapping individual ideas. Therefore, we can attribute the mobilization of learning in chemistry to the collective action characterized by this scheme.

Considering the results achieved through this research, it is recommended that learning strategies through collective action be implemented, by means of utilizing new educational technologies that represent challenge and motivation to students, so that they can engage more intensely in building their own knowledge.

\section{Acknowledgements}

This research was possible thanks to the support and collaboration of members from the Group of Research in Chemical Conception and Scientific Education (PECQ) from the Federal University of ABC (UFABC) and from the Pharmacy Course Coordination of the Faculty of Medicine of $A B C$ (FMABC).

\section{References}

Armbrecht, J. P., Aragón-Muriel, A., \& Micolda, G. (2014). Description and preliminary evaluation of a program for improving chemistry learning in high school students. Journal of Chemical Education, 91, 1439-1445. doi: 10.1021/ed400347z.

Bagarukayo, E., Weide, T., Mbarika, V., \& Kim, M. (2012). The impact of learning driven constructs on the perceived higher order cognitive skills improvement: multimedia vs. text. International Journal of Education and Development using Information and Communication Technology (IJEDICT), 8 (2), 120-130.

Bailey, S., Hendricks, S., \& Applewhite, S. (2015). Student perspectives of assessment strategies in online courses. Journal of Interactive Learning, 13 (3), 112-125.

Beltran, N. O. (1997). Ideias em movimento [Ideas in motion]. Química Nova na Escola, 5, 14-17.

Blonder, R., Jonatan, M., Bar-Dov, Z., Benny, N., Rap, S., \& Sakhnini, S. (2013). Can you tube it? Provinding chemistry teachers with technological tools and enhancing their self-efficacy beliefs. Chemistry Education Research and Practice, 14, 269-285. doi: 10.1039/c3rp00001j.

Bueno Filho, M. A. (2010). Conhecimento Estereoquímico na Acepção da Teoria dos Campos Conceituais [Stereochemical knowledge within the meaning of conceptual field theory]. $\mathrm{PhD}$ thesis presented at IQUSP, São Paulo.

Bueno Filho, M. A., Nascimento, M. G., \& Alves, G. N. (2015). Chemical concepts in motion: The role of collective schemes on the learning about intermolecular interactions. Problems of Education in the 21st Century, 68, 64-73.

Bronckart, J. P. (2007). De l'activité collective à l'action et à la pensée individuelles pour une psychologie fermement vygotskienne. In: Merri, M. (Ed.), Activité Humaine et Conceptualisation - Questions à Gérard Vergnaud [From collective activity to individual action and thought for a firmly Vygotskian psychology - questions to Gérard Vergnaud]. Tolousse: Presses Universitaires du Mirail, 121-141. [CD-ROM]. 
Caballero, C., Grings, E. T. O., \& Moreira, M. A. (2006). Possíveis indicadores de invariantes operatórios apresentados por estudantes em conceitos de termodinâmica [Possible indicators of operative invariants presented by students in concepts of thermodynamics]. Revista Brasileira de Ensino de Física, 28 (4), 463-471. doi: 10.1590/S1806-11172006000400009.

Caballero, C., Moreira, M. A., \& Stipcich, S. (2007). Un modelo para analizar las interaciones discursivas en classes de física [A model for analyzing discursive interactions in physics classes]. Revista Electrónica de Investigación en Ciencias (REIEC), 1, 1-21.

Caballero, C., Pesa, M., \& Bravo, S. (2009). Representaciones de alumnus universitarios sobre propagación de ondas mecânicas [Representations by university students on propagation of mechanical waves]. Enseñanza de las Ciencias, 27 (3), 405-420.

Carvalho Jr, G. D., \& Aguiar Jr, O. (2008). Os campos conceituais de Vergnaud como ferramenta para o planejamento didático [Vergnaud's conceptual fields as a tool for didactic planning]. Caderno Brasileiro de Ensino de Física, 25 (2). doi: 10.5007/2175-7941.2008v25n2p207.

Chiu, M. H., \& Wa, H. K. (2009). The roles of multimedia in the teaching and learning of the triplet relationship in chemistry. In: Gilbert, J. K, \& Treagust, D. (Eds.), Multiple representations in chemical education. Australia: Springer Science. doi: 10.1007/978-14020-8872-8.12.

Dejarnette, A. F., Walczak, M., \& González, G. (2014). Students' concepts- and theorems-in-action on a novel task about similarity. School Science and Mathematics, 114 (8), 05-414. doi: 10.1111/ ssm.12092.

Demissie, T., Ochonogor, C. E., \& Engida, T. (2011). Pedagogy-based-technology and chemistry students' performance in higher institutions: A case of Debre Berhan University. US-China Education Review, A5, 602-611.

Dunn, P. K., McDonald, C., \& Loch, B. (2015). Statscasts: Screencasts for complementing lectures in statistics classes. International Journal of Mathematical Education in Science and Technology, 46 (4), 521-532. doi: 10.1080/0020738X.2014.99053.

Johnstone, A. H. (1993). The development of chemistry teaching. Journal of Chemical Education, 70 (9), 701-705. doi: 10.1021/ed070p701.

Kim, M., \& Tan, H. T. (2013). A collaborative problem-solving process through environmental field studies. International Journal of Science Education, 35 (3), 357-387. doi: 10.1080/09500693.2012.752116.

Magina, S. M. P. (2011). A pesquisa na sala de aula de matemática das series iniciais do ensino fundamental. Contribuições teóricas da psicologia [The research in the mathematics classroom in the initial series of elementary school. Theoretical contributions of psychology]. Educar em Revista, 1, 63-75.

Magina, S. M. P., Santos, A., \& Merlini, V. L. (2014). O raciocínio de estudantes do ensino fundamental na resolução de situações de estruturas multiplicativas [The reasoning of students of elementary school in solving situations of multiplicative structures]. Ciências Educacionais, 20 (2), 517-533. doi: 10.1590/1516-73132014000200016.

Marcel, J. F. (2005). Le développement professionnel au travers de l'évolution des pratiques enseignantes [Professional development through the evolution of teaching practices]. Revue des Sciences de L'education, 31 (3), 585-606. doi: 10.7202/013911ar.

Marcel, J. F. (2009). Pratiques enseignants et scheme collectif [Teaching practices and collective scheme]. In: Merri, M. (Ed.), Activité Humaine et Conceptualisation - Questions à Gérard Vergnaud. Tolousse: Presses Universitaires du Mirail, 647-658. [CD-ROM].

Moraes, R., \& Galiazzi, M. C. (2006). Análise textual discursiva: processo reconstrutivo de múltiplas faces [Discursive textual analysis: Reconstructive process of multiple faces]. Ciência e Educação, $12(1), 117-128$.

Palangana, I. C. (1998). Desenvolvimento e Aprendizagem em Piaget e Vygotsky - A Relevância do Social [Development and learning in Piaget and Vygotsky - the social relevance]. São Paulo: Summus Editorial.

Rezende, D. B., \& Wartha, E. J. (2011). Os níveis de representação no ensino de química e as categorias da semiótica de Peirce [The levels of representation in the teaching of chemistry and the categories of Peirce's semiotic]. Investigações em Ensino de Ciências, 16 (2), 275-290. 
Lucia Machado de ANDRADE, Káthia Maria HONÓRIO, Marco Antonio BUENO FILHO. Collective action and collective scheme in the mobilization of learning chemistry according to Vergnaud's theory of conceptual fields

PROBLEMS

OF EDUCATION

IN THE $21^{\text {st }}$ CENTURY Vol. 75, No. 5, 2017

432

Sadik, A. (2015). Students' preferences for types of video lectures: lecture capture vs. screencasting recordings. International Journal of Higher Education, 4 (4), 94-104. doi: 10.5430/ijhe.v4n4p94.

Sánchez, A. B., \& Fernández, R. L. (2011). La transferencia de aprendizaje algorítmico y el origen de los errores en la sustracción [The transfer of algorithmic learning and the origin of the errors in the substraction]. Revista de Educación, 354, 429-445.

Sherer, P., \& Shea, T. (2011). Using online video to support student learning and engagement. College Teaching, 59, 56-59. doi: 10.1080/87567555.2010.511313.

Smith, D. K. (2014). Itube, youtube, wetube: Social media videos in chemistry education and outreach. Journal of Chemical Education, 91 (10), 1594-1599. doi: 10.1021/ed400715s.

Suart, R, C. (2008). Habilidades Cognitivas Manifestadas por Alunos do Ensino Médio de Química em Atividades Experimentais Investigativas [Cognitive skills manifested by high school chemistry students in experimental investigative activities]. MSc. dissertation presented at FEUSP, IFUSP and IQUSP, São Paulo.

Talanquer, V. (2014). Simulaciones computacionales para explorar y construir modelos [Computational simulations to explore and construct models]. Didáctica de las Ciencias Experimentales, 76, 8-16.

Talanquer, V. (2011). Macro, submicro, and symbolic: The many faces of the chemistry "triplet". International Journal of Science Educaton, 33 (2), 179-195. doi: 10.1080/09500690903386435.

Taqi, H. A., \& Al-Nouh, N. A. (2014). Effect of group work on EFL students' attitudes and learning in higher education. Journal of Education and Learning, 3 (2), 52-65. doi: 10.5539/jel.v3n2p52.

Treagust, D. F., Schmidt, H. J., \& Kaufmann, B. (2009). Students' understanding of boiling points and intermolecular forces. Chemistry Education Research and Practice, 10, 265-272. doi: 10.1039/ B920829C.

Turkoguz, S. (2012). Learn to teach chemistry using visual media tools. Chemistry Education Research and Practice, 13, 401-409. doi: 10.1039/c2rp20046e.

Verdier, P. (2007). Conceptualiser: du collectif à l'individuel (et vice-versa) [Conceptualize: From the collective to the individual (and vice-versa)]. In: Merri, M. (Ed.), Activité Humaine et Conceptualisation - Questions à Gérard Vergnaud. Tolousse: Presses Universitaires du Mirail, 693-696. [CD-ROM].

Vergnaud, G. (2012). Forme operatoire et forme predicative de la connaissance [Operative form and predicative form of knowledge]. Investigações em Ensino de Ciências, 17 (2), 287-304.

Vergnaud, G. (2009). The theory of conceptual fields. Human Development, 52, 83-94. doi: $10.1159 / 000202727$.

Vergnaud, G. (2003). A gênese dos campos conceituais. Por que há quem ainda não aprende? [The genesis of conceptual fields: Why are there people who still do not learn?]. Rio de Janeiro: Editora Vozes.

Vergnaud, G. (1991). La théorie des champs conceptuels [The conceptual fields theory]. Recherches en Didactique des Mathématiques, 10 (23), 133-170.

WCER, Wisconsin Center for Educational Research. Transana: Qualitative analysis software for video and audio data. Madison, WI: autor. Retrieved from http://www.transana.org/.

Zoller, U., \& Scholz, R. W. (2004). The HOCS paradigm shift from disciplinary knowledge (LOCS) - to interdisciplinary evaluative, system thinking (HOCS): What should it take in science-technologyenvironment-society oriented courses, curricula and assessment? Water Science and Technology, 49 (8), 27-36.

Zoller, U. (2001). Altenative assessment as (critical) means of facilitating HOCS-promoting teaching and learning in chemistry education. Chemistry Education: Research and Practice in Europe, 2 (1), 9-17. doi: 10.1039/B1RP90004H.

Zoller, U. (2000). Interdisciplinary systemic HOCS development - the key for meaningful STES oriented chemical education. Chemistry Education: Research and Practice in Europe, 1 (2), 189-200. doi: 10.1039/A9RP90021G.

Zoller, U. (1999). Scaling-up of higher-order cognitive skills-oriented college chemistry teaching: An action-oriented research. Journal of Research Science Teaching, 36 (5), 583-596. doi: 0.1002/ (SICI)1098-2736(199905)36:5<583::AID-TEA5>3.0.CO;2-M. 
Lucia Machado de ANDRADE, Káthia Maria HONÓRIO, Marco Antonio BUENO FILHO. Collective action and collective scheme in the mobilization of learning chemistry according to Vergnaud's theory of conceptual fields

ROBLEMS

OF EDUCATION

IN THE $21^{\text {st }}$ CENTURY

Vol. 75, No. 5, 2017

Zoller, U. (1993). Are lecture and learning compatible? Maybe for LOCS: unlikely for HOCS. Journal of 433 Chemical Education, 70 (3), 195-197. doi: 10.1021/ed070p195.

Received: July 05, 2017

Accepted: September 20, 2017

\begin{tabular}{|ll} 
Lucia Machado de Andrade & PhD, Professor, FMABC, Av. Príncipe de Gales, 821, Santo André, São \\
& Paulo, Brazil, CEP 09060-650. \\
& E-mail: lucia.andrade@ufabc.edu.br \\
& Website: http://pesquisa.ufabc.edu.br/pecq/ \\
\hline \multirow{2}{*}{ Kathia Maria Honório } & PhD, Professor, UFABC, Av. dos Estados, 5001, Santo André, São Paulo, \\
& Brazil, CEP 09210-580. \\
& E-mail: kmhonorio@usp.br \\
\hline \multirow{3}{*}{ Marco Antonio Bueno Filho } & PhD, Professor, UFABC, Av. dos Estados, 5001, Santo André, São Paulo, \\
& Brazil, CEP 09210-580. \\
& E-mail: marco.antonio@ufabc.edu.br \\
& Website: http://pesquisa.ufabc.edu.br/pecq/
\end{tabular}

